\title{
HEAVY-SECTION STEEL IRRADIATION PROGRAM ON IRRADIATION EFFECTS IN LIGHT-WATER REACTOR PRESSURE VESSEL MATERIALS*
}

Randy K. Nanstad, William R. Corwin, David J. Alexander, Fahmy M. Haggag, Shafik K. Iskander, Donald E. McCabe, Mikhail A. Sokolov, $†$ and Roger E. Stoller

\author{
Metals and Ceramics Division \\ OAK RIDGE NATIONAL LABORATORY \\ Oak Ridge, Tennessee
}

\begin{abstract}
${ }^{*}$ Research sponsored by the Office of Nuclear Regulatory Research, Division of Engineering, U.S. Nuclear Regulatory Commission, under Interagency Agreement DOE 1886-8109-8L with the U.S. Department of Energy under Contract DE-AC05-84 OR21400 with Martin Marietta Energy Systems, Inc.
\end{abstract}

† Postdoctoral researcher.

The submitted manuscript has been authored by

a contractor of the U.S. Government under contract No. DE-AC05-84OR21400. Accordingly,

the U.S. Government retains a nonexclusive,

royalty-free license to publish of reproduce the

published form of this contribution, or allow olhers

to do so, for U.S. Government purposes. 


\section{DISCLAIMER}

Portions of this document may be illegible in electronic image products. Images are produced from the best available original document. 


\title{
HEAVY-SECTION STEEL IRRADIATION PROGRAM ON IRRADIATION EFFECTS IN LIGHT-WATER REACTOR PRESSURE VESSEL MATERIALS
}

\author{
Randy K. Nanstad, William R. Corwin, David J. Alexander, \\ Fahmy M. Haggag, Shafik K. Iskander, Donald E. McCabe, \\ Mikhail A. Sokolov, and Roger E. Stoller \\ Metals and Ceramics Division \\ Oak Ridge National Laboratory \\ Oak Ridge, Tennessee
}

\begin{abstract}
The safety of commercial light-water nuclear plants is highly dependent on the structural integrity of the reactor pressure vessel (RPV). In the absence of radiation damage to the RPV, fracture of the vessel is difficult to postulate. Exposure to high energy neutrons can result in embrittlement of radiation-sensitive RPV materials. The Heavy-Section Steel Irradiation (HSSI) Program at Oak Ridge National Laboratory, sponsored by the U.S. Nuclear Regulatory Commission (USNRC), is assessing the effects of neutron irradiation on RPV material behavior, especially fracture toughness. The results of these and other studies are used by the USNRC in the evaluation of RPV integrity and regulation of overall nuclear plant safety. In assessing the effects of irradiation, prototypic RPV materials are characterized in the unirradiated condition and exposed to radiation under varying conditions. Mechanical property tests are conducted to provide data which can be used in the development of guidelines for structural integrity evaluations, while metallurgical examinations and mechanistic modeling are performed to improve understanding of the mechanisms responsible for embrittlement. The results of these investigations, in conjunction with results from commercial reactor surveillance programs, are used to develop a methodology for the prediction of radiation effects on RPV materials. This irradiation-induced degradation of the materials can be mitigated by thermal annealing, i.e., heating the RPV to a temperature above that of normal operation. Thus, thermal annealing and evaluation of reirradiation behavior are major tasks of the HSSI Program. This paper describes the HSSI Program activities by summarizing some past and recent results, as well as current and planned studies.
\end{abstract}

\section{INTRODUCTION}

The degrading effects of neutron irradiation on carbon and low-alloy pressure vessel steels have been recognized and investigated since the early 1950s. In those steels at light-water-reactor (LWR) operating temperatures $\left(-288^{\circ} \mathrm{C}\right)$, radiation damage is produced when neutrons of sufficient energy displace atoms from their lattice sites. The defects formed in the steel as a result of those displacements typically cause hardening and a decrease in toughness. Tensile behavior exhibits an increase in yield strength, a decrease in the ultimate to yield strength ratio, and a loss of ductility as measured by specimen elongation. The decrease in toughness is most commonly represented by an increase in the ductile-brittle transition temperature and a decrease of the uppershelf energy as measured by the Charpy V-notch (CVN) impact test. The synergistic effects of neutron fluence, flux, and spectrum, the irradiation temperature, and the chemical composition and microstructure of the steel must be understood to allow for reductions in uncertainties associated with the development of predictive models. When the Heavy-Section Steel Technology (HSST) Program was initiated in 1967, irradiation effects was one of the designated major topics of investigation. [In 1989, the HSST Program irradiation effects task was organized into a separate Heavy-Section Steel Irradiation (HSSI) Program, and all the irradiation series are now referred to as HSSI Program Series, e.g., HSSI Program Irradiation Series 2 and 3.] It was well recognized that the effects of irradiation could degrade the materials, but definitive effects on fracture properties, especially in thick sections, were not available. At that time, the field of fracture mechanics was in the early stages and even the amount of data on other material properties under LWR conditions was deficient. During the intervening time, "Title 10," Part 50 of the Code of Federal Regulations (10CFR50) evolved to include requirements for fracture toughness of reactor pressure vessels (RPVs). Those requirements include surveillance testing: $\mathrm{CVN}$ specimens are required, tensile specimens are recommended, and fracture toughness specimens are required if the surveillance materials are predicted to exhibit marginal properties. Furthermore, 10CFR50 requires prediction of radiation effects using Regulatory Guide 1.99 (Rev. 2) and, if those predictions indicate unacceptable end-of-life toughness, the vessel must be designed to accommodate thermal annealing. Additionally, criteria are 
8pecified for toughness transition temperatures which, if attained by the surveillance tests, require plant-specific analyses to demonstrate adequate protection against pressurized thermal shock. As part of those requirements, 10CFR50 refers to the American Society of Mechanical Engineers (ASME) Boiler and Pressure Vessel Code, Sects. III and XI, for fracture toughness requirements and American Society for Testing and Materials (ASTM) E 185 for surveillance testing and analysis as well as application of the test results.

The HSSI Program incorporates four basic objectives: (1) experimental determination of neutron irradiation effects; (2) validation of experimental results; (3) application of results; and (4) technical assistance in support of other U.S. Nuclear Regulatory Commission (USNRC) designated investigations. The following major program elements have been included within the HSSI Program: experimental investigation and verification of the irradiation-induced loss of fracture resistance in critical reactor vessel materials, with an emphasis on applicability of results from small and moderate sized specimens to the thick sections used in reactor pressure vessel (RPV) construction; experimental verification and expansion of existing data on annealing recovery and subsequent reembrittlement in critical pressure vessel materials to provide a validated basis for remedial actions for severely embrittled vessels; coordinated, advanced microstructural examinations and physically based theoretical model development of controlling microstructural mechanisms to provide improved predictions of macroscopic embrittlement; verification of predictions of radiation-induced damage by examination of materials exposed during actual service; and maintaining the supply of correlation monitor material used for validating results of worldwide irradiation surveillance programs. This paper describes the HSSI Program activities by summarizing some past and recent results, as well as current and planned studies.

\section{HSSI PROGRAM IRRADIATION STUDIES}

In 1972, following the completion of irradiation studies already under way when the program was initiated, the HSST Program began a series of irradiation experiments in response to the need for information regarding the effects of neutron irradiation on the mechanical properties, particularly fracture toughness, of light-water nuclear RPV steels. Much research had already been performed in the area of linear-elastic fracture mechanics for unirradiated materials, and, for these conditions, the effects of specimen size and temperature were known. The Welding Research Council (WRC) published WRC Bulletin 175 in August 1972 and established a reference stress intensity $\left(K_{R}\right)$ curve that was constructed as a lower bound to $K_{i k}, K_{k d}$, and $K_{\text {data available for } A} 533$ grade B class 1 and A 508 steels. This curve was incorporated into the ASME Boiler and Pressure Vessel Code and is used as a guideline for operation of reactors to provide protection against nonductile failure. The effects of irradiation on initiation fracture toughness $\left(K_{k}\right.$ and $\left.K_{y d}\right)$ were not well understood and there was no such information on crack-arrest toughness $\left(K_{b}\right)$.

The irradiation effects research currently includes eleven separate major experimental series; six have been completed, two are active, and three are under planning. Additionally, a major task on the investigation of microstructural changes induced by irradiation and the modeling of their effects was initiated in 1989 to provide a better understanding of the metallurgical mechanisms governing embrittlement. This section briefly summarizes the various completed, ongoing, and future series as well as the results from the microstructural analysis and modeling work. Major attributes of all irradiation series are described in Table 1.

The first four irradiation series dealt with dynamic fracture, ductile tearing resistance of low upper-shelf (LUS) welds, and fracture toughness of welds fabricated using current welding practice. Series 5 and 6 incorporated a large number of small and large specimens (up to 203-mm-thick compact specimens) of two welds to provide a basis for statistical analyses used to determine the temperature shitt and shape of the postirradiation $K_{k}$ and $K_{k}$ curves. Series 7 examined the overall irradiation-induced degradation of stainless steel cladding. Series 9 is examining the effects of thermal annealing with particular emphasis on reembrittlement rates and the relationship between the amount of recovery measured by impact testing as compared to fracture toughness recovery. Series 10 is examining the overall fracture toughness of a commercial LUS weld from the Midland Unit 1 reactor vessel. Series 8 , on the $K_{t c}$ curve shift and shape for LUS welds, and Series 11 , on embrittlement in plate and heat-affected zone (HAZ) materials, are in various stages of planning.

\section{Early Irradiation Projects}

When the HSST Program was initiated in 1967, the United States Atomic Energy Commission (USAEC) had, in fact, already sponsored two irradiation effects projects, and the HSST Program assumed managerial responsibility for them and for the formulation of plans for extensions of those projects. The U.S.-Euratom Joint Research and Development Program was then being coordinated by Westinghouse Electric Corporation while the Iradiation Effects to Heavy-Section Pressure Vessel Steels Program was coordinated by Battelle Pacific Northwest Laboratories (PNL). Both of those programs were directed toward fracture toughness using developmental specimens of limited size. The largest specimens used were $50.8 \mathrm{~mm}(2$ in.) thick. Prior irradiation effects research demonstrated clearly that neutron irradiation could severely degrade the CVN impact toughness of ferritic steels, but the effects on initiation fracture toughness, $K_{\mathbf{k}}$, had not been demonstrated. It is also important to note that the ASTM standard for fracture toughness testing was in the early stages of development. The results from those early programs, however, were important in that they showed irradiation-induced degradation of fracture toughness, a strong temperature dependence of postirradiation fracture toughness, and a need for larger specimens (Whitman, 1986). Figure 1 shows some results from the Westinghouse program (Mager, 1970). The highest fracture toughness values measured which satisfied the suggested ASTM criteria were about $82 \mathrm{MPa} \sqrt{m}$ (75 ksivin).

The PNL program determined that the double-cantilever beam specimen offered no advantage over the compact specimen geometry in terms of irradiation experiments and, more importantly, that the measuring capacity of the compact specimen was higher for a given thickness. It also showed that the $K_{k}$ temperature shift was about the same as the CVN 41-J (30-ft-lb) shift and that postirradiation annealing of tensile specimens at $385^{\circ} \mathrm{C}\left(725^{\circ} \mathrm{F}\right)$ resulted in significant recovery of properties (Whitman, 1986).

\section{Series 1 - Dynamic Fracture Toughness Using Large Specimens}

The objective of Series 1 was to verify that high values of fracture toughness under dynamic (high loading rate) conditions could be achieved in material irradiated to typical reactor vessel end-of-life neutron fluence $\left[\approx 2 \times 10^{19}\right.$ neutrons $\left./ \mathrm{cm}^{2}(>1 \mathrm{MeV})\right]$. The irradiation 
Table 1. Summary of HSST/HSSI Irradiation Series - March 1995

\begin{tabular}{|c|c|c|c|c|c|c|c|}
\hline $\begin{array}{l}\text { Irradiation } \\
\text { series No. }\end{array}$ & Objective & Materials & $\begin{array}{l}\text { Specimen } \\
\text { complement }\end{array}$ & $\begin{array}{c}\begin{array}{c}\text { Reactor } \\
\text { irradiation } \\
\text { dates }\end{array} \\
\end{array}$ & $\begin{array}{c}\text { Neutron fluence } \\
\text { [neutrons } / \mathrm{cm}^{2} \\
(\mathrm{E}>1 \mathrm{MeV})]\end{array}$ & $\begin{array}{c}\text { Irradiation } \\
\text { temperature } \\
{\left[{ }^{\circ} \mathrm{C}\left({ }^{\circ} \mathrm{F}\right)\right]}\end{array}$ & Comments \\
\hline 1 & $\begin{array}{l}\text { Upper transition - } \\
\text { fracture toughness of } \\
\text { plate and weld metal }\end{array}$ & $\begin{array}{l}\text { A533 grade B class } 1 \text { (plate 02), } \\
\text { submerged-arc weld metal }\end{array}$ & $\begin{array}{l}\text { TCS }-6 \\
\text { CVCS }-140 \\
\text { CVN }-154 \\
\text { Ten }-34 \\
\end{array}$ & $\begin{array}{l}\text { Battelle Research Reactor, } \\
\text { Columbus, Ohio; } \\
\text { Westinghouse conducted } \\
10 / 20 / 72 \text { to } 12 / 13 / 73 \\
\end{array}$ & $2.2-7.0 \times 10^{19}$ & $\begin{array}{l}270-300 \\
(515-570)\end{array}$ & $\begin{array}{l}\text { Status: program completed } \\
\text { HEDL-TME 75-10; WCAP-8775 } \\
\text { ORNL/TM-4729/VII }\end{array}$ \\
\hline 2 & $\begin{array}{l}\text { Ductile shelf - } \\
\text { fracture toughness of low } \\
\mathrm{CV} \text { shelf material }\end{array}$ & $\begin{array}{l}\text { Low-shelf submerged arc weld } \\
\text { metal, } 61 W, 62 W, 63 W ; C u \text { : } \\
0.29,0.21,0.30 \%\end{array}$ & $\begin{array}{l}\text { TTCS }-6 \\
1.6 \text { TCS }-6 \\
0.8 T C S-12 \\
0.5 T C S-117 \\
\text { CVN }-207 \\
\text { Ten }-27 \\
\end{array}$ & $\begin{array}{l}\text { Bulk Shielding Reactor, } \\
\text { Oak Ridge. Tenn.; } \\
\text { 10/15/76 to } 3 / 3 / 77\end{array}$ & $0.4-2.1 \times 10^{19}$ & $\begin{array}{l}233-343 \\
(450-650)\end{array}$ & $\begin{array}{l}\text { Status: program completed } \\
\text { NUREG/CR-5696 (ORNL/TM-11804) } \\
\text { NUREG/CR-3506 (MEA-2028) }\end{array}$ \\
\hline 3 & $\begin{array}{l}\text { Ductile shelf- } \\
\text { fracture toughness of low } \\
\mathrm{CV} \text { shelf weld material }\end{array}$ & $\begin{array}{l}\text { Low-shelf submerged arc weld } \\
\text { metal, } 64 \mathrm{~W}, 65 \mathrm{~W}, 66 \mathrm{~W}, 67 \mathrm{~W} \text {; } \\
\text { Cu: } 0.35,0.22,0.42,0.27 \%\end{array}$ & $\begin{array}{l}\text { TTCS }-6 \\
1.6 \mathrm{TCS}-6 \\
0.8 \mathrm{TCS}-12 \\
0.5 \mathrm{TCS}-117 \\
\text { CVN }-207 \\
\text { Ten }-27 \\
\end{array}$ & $\begin{array}{l}\text { Bulk Shielding Reactor, } \\
\text { Oak Ridge, Tenn.; } \\
12 / 19 / 77 \text { to } 3 / 29 / 78\end{array}$ & $0.4-1.2 \times 10^{19}$ & $\begin{array}{l}233-310 \\
(450-590)\end{array}$ & $\begin{array}{l}\text { Status: program completed } \\
\text { NUREG/CR-5696 (ORNL/TM-11804) } \\
\text { NUREG/CR-3506 (MEA-2028) }\end{array}$ \\
\hline 4 & $\begin{array}{l}\text { Ductile shelf- } \\
\text { fracture toughness of } \\
\text { state-of-the-art weld } \\
\text { material }\end{array}$ & $\begin{array}{l}\text { A533 grade B class } 1 \text { (plate 02), } \\
\text { current practice submerged arc } \\
\text { weld metal, 68W, 69W, 70W, } \\
\text { 71W; Cu: }<0.10,2 \text { FRG matls. }\end{array}$ & $\begin{array}{l}\text { ITCS }-240 \\
\text { CVN }-348 \\
\text { Ten }-52\end{array}$ & $\begin{array}{l}\text { Bulk Shielding Reactor, } \\
\text { Oak Ridge, Tenn.; } \\
12 / 18 / 79 \text { to } 7 / 25 / 82\end{array}$ & $0.5-2.7 \times 10^{19}$ & $288(550)$ & $\begin{array}{l}\text { Status: program completed } \\
\text { NUREG/CR-4880 (ORNL6484) }\end{array}$ \\
\hline 5 & $\begin{array}{l}\text { KIc curve shift- } \\
\text { compare with CVN curve } \\
\text { shift; } K_{I c} \text { values high as } \\
\text { possible }\end{array}$ & $\begin{array}{l}\text { Submerged-arc weld metals, Cu: } \\
0.23,0.31 \% \text {, no copper coated } \\
\text { electrodes, copper added to } \\
\text { melt }\end{array}$ & $\begin{array}{l}\text { 4TCS }-16 \\
\text { 2TCS }-36 \\
\text { 1TCS }-60 \\
\text { CVN }-112 \\
\text { Ten }-32 \\
\text { DWT }-32 \\
\end{array}$ & $\begin{array}{l}\text { Oak Ridge Research } \\
\text { Reactor, Oak Ridge, } \\
\text { Tenn; } 5 / 11 / 84-12 / 13 / 85\end{array}$ & $\begin{array}{l}1.5 \times 10^{19} \text { and } \\
5.0 \times 10^{19}\end{array}$ & $288(550)$ & $\begin{array}{l}\text { Status: first phase of program to } 1.5 \times 10^{19} \\
\text { completed, second phase } 105 \times 10^{19} \\
\text { planned. } \\
\text { NUREC/CR-5913 (ORNL/TM-12156) }\end{array}$ \\
\hline 6 & $\begin{array}{l}\text { KIa curve shift - } \\
\text { compare with CVN and } \\
\text { KIc curve shifts }\end{array}$ & $\begin{array}{l}\text { Submerged-arc weld metals, Cu: } \\
0.23,0.31 \%, \text { no copper coated } \\
\text { electrodes, copper added to } \\
\text { melt }\end{array}$ & $\begin{array}{l}\text { ITCA - 14 } \\
1.3 \mathrm{TCA}-30 \\
(24 \text { duplex) } \\
1 \times 3 \times 3-16\end{array}$ & $\begin{array}{l}\text { Oak Ridge Research } \\
\text { Reactor, Oak Ridge, } \\
\text { Tenn.; 12/23/85-5/2/86 }\end{array}$ & $1.8 \times 10^{19}$ & $288(550)$ & $\begin{array}{l}\text { Status: program completed } \\
\text { NUREG/CR-5584 (ORNL/TM-11575) } \\
\text { NUREG/CR-6139 (ORNL/TM 12513) }\end{array}$ \\
\hline 7 & $\begin{array}{l}\text { Stainless steel cladding - } \\
\text { fracture toughness of } \\
\text { submerged-arc stainless } \\
\text { steel cladding }\end{array}$ & $\begin{array}{l}309 / 308 \text { single-wire oscillating } \\
\text { and } 308 \text { three-wire series arc }\end{array}$ & $\begin{array}{l}\text { CVN-110 } \\
\text { Ten }-30 \\
0.5 \text { TCS }-48\end{array}$ & $\begin{array}{l}\text { Nuclear Science and } \\
\text { Technology Facility, } \\
\text { Buffalo, N.Y.; one-wire } \\
\text { Irradiated 1983, thre- } \\
\text { wire } 9 / 85-3 / 86 \\
\end{array}$ & 1,2 , and $5 \times 10^{19}$ & $288(550)$ & $\begin{array}{l}\text { Status: program completed } \\
\text { Except for precracked CVN } \\
\text { NUREG/CR-5511 (ORNL/TM-11439) } \\
\text { NUREG/CR-3927 (ORNL/TM-9309) }\end{array}$ \\
\hline 8 & $\begin{array}{l}\text { KIc \& } \mathrm{K}_{\text {In }} \text { curve shifts- } \\
\text { compare with CVN curve } \\
\text { shift and examine change } \\
\text { in shape }\end{array}$ & $\begin{array}{l}\text { Planned: } \\
\text { Low-shelf submerged-arc weld } \\
\text { metal, Cu: } 0.30 \text { to } 40 \%\end{array}$ & $\begin{array}{l}\text { Planned: } \\
0.5-2 \text { TCS } \\
1.0-1.3 T C A \\
\text { CVN, Ten }\end{array}$ & $\begin{array}{l}\text { University of Michigan, } \\
\text { Ford Reactor, Ann } \\
\text { Arbor, Mich. } \\
\text { Irradiations to begin } 1 / 99\end{array}$ & $\begin{array}{l}\text { Target: } \\
1.5 \times 10^{19}\end{array}$ & $\begin{array}{l}\text { Target: } \\
288 \text { (550) }\end{array}$ & $\begin{array}{l}\text { Status: conceptually planned, lest materials } \\
\text { under development }\end{array}$ \\
\hline 9 & $\begin{array}{l}\text { Annealing and } \\
\text { reembrittlement- } \\
\text { compare fracture } \\
\text { toughness and CVN } \\
\text { response }\end{array}$ & $\begin{array}{l}\text { Planned: } \\
\text { Low-shelf submerged-arc weld } \\
\text { metals, Cu: } 0.30 \text { to } 48 \% \text {, } \\
\text { includes WF-70 from } \\
\text { Midland) }\end{array}$ & $\begin{array}{l}\text { Planned: } \\
0.5-2 \text { TCS } \\
1.0-1.3 T C A \\
\text { CVN, Ten }\end{array}$ & $\begin{array}{l}\text { University of Michigan, } \\
\text { Ford Reactor, Ann } \\
\text { Arbor, Mich. Scoping } \\
\text { irradiations to begin } 1 / 96\end{array}$ & $\begin{array}{l}\text { Targets: } \\
\text { Irrad. } 0.1,0.5, \& \\
2.0 \times 10^{19} \\
\text { Reirrad. } 0.1,0.5,8 \\
1.0 \times 10^{19}\end{array}$ & $\begin{array}{l}\text { Target: } \\
288 \text { (550) }\end{array}$ & $\begin{array}{l}\text { Status: Scoping tests in progress, } \\
\text { conceptually planned, remaining test } \\
\text { materials under development }\end{array}$ \\
\hline 10 & $\begin{array}{l}\text { Commercial low CV shelf } \\
\text { weld embrittlement- } \\
\text { upper shelf and shift } \\
\text { determinations }\end{array}$ & $\begin{array}{l}\text { Low-shelf submerged-arc weld } \\
\text { metal from Midland reactor } \\
\text { vessel, Cu: } 0.30 \text { to } 48 \% \text { (plus } \\
\text { high-copper submerged-arc } \\
\text { weld metal from Series } 5 \text { \& } 6 \text {. } \\
\text { cladding, end Russian sleele) }\end{array}$ & $\begin{array}{l}\text { TTCS }-2 \\
1 \text { TCS }-81 \\
0.5 T C S-64 \\
\text { CVN }-548 \\
\text { Ten }-78 \\
1-1.3 \text { TCA }-15\end{array}$ & $\begin{array}{l}\text { University of Michigan, } \\
\text { Ford Reactor, Ann } \\
\text { Arbor, Mich. } \\
\text { Irradiations began 4/92 }\end{array}$ & $\begin{array}{l}\text { Target: } \\
0.5,2.0, \text { and } \\
5.0 \times 10^{19}\end{array}$ & $\begin{array}{l}\text { Target: } \\
288 \text { (550) }\end{array}$ & $\begin{array}{l}\text { Status: unirradiated testing and low- to } \\
\text { moderate- fluence irradiations complete, } \\
\text { irradiated testing in progress } \\
\text { NUREG/CR-5914 (ORNL-6740) } \\
\text { NUREG/CR-6249 (ORNL/TM-12Tm) }\end{array}$ \\
\hline$\pi$ & $\begin{array}{l}\text { HAZ embrittlement- } \\
\text { upper shelf and shift } \\
\text { determinations }\end{array}$ & $\begin{array}{l}\text { A302 grade B plate heat } \\
\text { affected zone material, Cu: } \\
0.16 \text { to } 0.32 \%\end{array}$ & $\begin{array}{l}\text { Planned: } \\
\text { 0.5-1TCS } \\
\text { 1.0-1.3TCA } \\
\text { CVN, Ten } \\
\end{array}$ & $\begin{array}{l}\text { University of Michigan, } \\
\text { Ford Reactor, Ann } \\
\text { Arbor, Mich. } \\
\text { Irradiations to begin } 6 / 96\end{array}$ & $\begin{array}{l}\text { Trrad. Target: } \\
2.0 \times 10^{19}\end{array}$ & $\begin{array}{l}\text { Target: } \\
288(550)\end{array}$ & $\begin{array}{l}\text { Status: Conceptually planned, test } \\
\text { materials being determined }\end{array}$ \\
\hline
\end{tabular}


of large fracture mechanics specimens represents a major factor in the HSST and HSSI irradiation series. In terms of linear elastic fracture mechanics, the $K_{k}$ measuring capacity increases with the square root of increasing specimen thickness. Series 1 examined static and dynamic fracture toughness with $100-\mathrm{mm}[4 \mathrm{TC}(\mathrm{T})]$ compact specimens. That size was determined to be the practical upper limit beyond which neutron fluence variations through the thickness and gamma heating would be excessive. Both base plate and submerged-arc weld metal were studied. The results of Series 1 showed that initiation fracture toughness vs test temperature curves shifted to higher temperatures by an amount approximated by the shift in CVN test results and that fracture initiation toughness reached high values at the higher test temperatures even after irradiation (Fig. 2). However, few specimens of the larger sizes were irradiated and tested, and statistical analysis was not possible (Williams, 1975), (Davidson et al., 1976).

A critical factor in the performance of these irradiations was the development of a capsule for the specimens that would minimize temperature and neutron fluence gradients in the specimens. The internal generation of heat due to gamma ray exposure was overcome by incorporation of flowing gas through gas gaps to reject heat and electric heaters to control the temperature gradient through the specimen thickness. Later improvements in capsule design incorporated a separate gamma shield and controllable zoned heaters to provide excellent temperature control. This series also demonstrated that large specimens could be irradiated to reactor vessel end-of-life fluences in a practical manner and with acceptable control of temperature and fluence gradients.

\section{Series 2 and 3 - Ductile Shelf Fracture Toughness} with 4TC(T)

In late 1968, Potapovs and Hawthome (1968), (1969) had reported that some residual elements, particularly copper, increased irradiation sensitivity. Until this time a number of vessels were fabricated with welds that contained high levels of copper from flashing on the weld wire. Not only was the susceptibility to irradiation damage enhanced by the presence of the copper, but the materials also exhibited low upper-shelf toughness, with projections of large decreases in ductile toughness from the projected neutron fluences before end of life. The levels were predicted to go below the 68-J (50-ft-lb) Charpy energy level, which would require special analysis in accordance with 10CFR50, Appendix G, Fracture Toughness Requirements.

Irradiation Series 2 and 3 were initiated in November 1975 to investigate the postirradiation ductile fracture toughness of these LUS welds and were to include the use of large fracture mechanics specimens. Six submerged-are welds were supplied by Babcock and Wilcox $\mathrm{Co}$. and one weld was supplied by Westinghouse, all fabricated with copper-coated wire and Linde 80 flux. Mean copper contents ranged from 0.21 to $0.42 \mathrm{wt} \%$. In addition to the capsule fabrication and irradiation requirements, a separate and complicated objective was the development of experimental procedures for obtaining as much data as practicable from each specimen to facilitate ductile instability analyses. Considerable effort was expended by many organizations in concluding that the single specimen unlaading compliance procedure should be used to obtain J-integral resistance (J-R) curves (Whitman, 1986).

The irradiation and testing program included $\mathrm{CVN}$, tensile, precracked CVN, $0.5 \mathrm{~T}-, 0.8 \mathrm{~T}-, 1.6 \mathrm{~T}$-, and $4 \mathrm{TC}(\mathrm{T})$. The irradiation temperature at the crack-tip region on the $4 \mathrm{TC}(\mathrm{T})$ was controlled at $288^{\circ} \mathrm{C}\left(550^{\circ} \mathrm{F}\right)$, while the temperatures for the smaller specimens, located in the notches and pinholes of the large specimens, varied significantly. Fluences varied from 0.4 to $2.1 \times 10^{19}$ neutrons $/ \mathrm{cm}^{2}$ $(>1 \mathrm{MeV})$.

The two test series produced very valuable data directly related to structural integrity analyses of reactor pressure vessels containing LUS welds in regions of high neutron flux. Their results can be summarized as follows: (1) a data base of J-R curves for irradiated low upper-shelf welds was established for use in elastic-plastic fracture mechanics analyses of reactor pressure vessels; (2) irradiation to $\approx 1 \times 10^{19}$ neutrons/ $\mathrm{cm}^{2}(>1 \mathrm{MeV}$ ) substantially decreased both the ductile initiation toughness, $J_{k}$, and tearing modulus; (3) the tearing modulus is a more discriminating indicator of degradation than $\mathrm{J}_{\mathbf{k}}$; (4) no specimen size effects were observed for irradiated LUS welds; (5) a correlation was developed between J-R curve parameters and CVN upper-shelf energy which offers potential for use in interpretation of surveillance data from CVN specimens; and (6) the CVN results showed Regulatory Guide 1.99 to be generally conservative for these test reactor irradiations (Hiser et al., 1984), (Hiser et al., 1985), (McGowan, 1985), (Nanstad and Berggren, 1993). Figure 3 shows an example of the irradiation-induced degradation of J-R curves for one of the welds.

\section{Series 4 - Fracture Toughness of State-of-the-Art Welds}

Series 4 was also a ductile-shelf study, except that the submerged-arc welds examined were fabricated with low-copper content and current-practice welding procedures, using the same plate material (HSST Plate 02) used in Series 1. Low upper-shelf materials from the Federal Republic of Germany were also included in this study. Series 4 included only ITC(T) in addition to the Charpy and tensile specimens. Sufficient specimens existed to perform statistical analyses of the results, a factor that was lacking in the previous series. Series 4 demonstrated that low-copper submerged-are welds fabricated with current practices show relatively small radiation-induced shifts of fracture toughness and little or no decrease of ductile fracture toughness, $J_{k c}$ and tearing resistance (Berggren et al., 1985), (McGowan and Nanstad, 1987). Figure 4 shows a typical result for one of the welds. These data show that state-of-the-art weldments can be produced that have virtual immunity to radiation damage, and inherently high levels of fracture toughness can be expected throughout the design lifetime of the plant.

\section{Series 5 and $6-K_{1}$ and $K_{2}$ Curve Shift and Shape}

To account for the effects of neutron irradiation on toughness, the initiation and arrest fracture toughness curves as described in Sect. XI of the ASME Boiler and Pressure Vessel Code are shifted upward in temperature without change in shape by an amount equal to the shift (plus a margin term) of the CVN impact energy curve at the $41-\mathrm{J}$ (30-ft-lb) level. Such a procedure implies that the shifts in the fracture toughness curves are the same as those at the CVN $41-\mathrm{J}(30-\mathrm{ft}-\mathrm{lb})$ energy level, and that irradiation does not change the shapes of the fracture toughness curves.

The objectives of the Fifth and Sixth Irradiation Series were to determine the $K_{k}$ and $K_{k}$ curve shifts and shapes for two irradiated high-copper $(0.23$ and $0.31 \mathrm{wt} \%)$ submerged-are welds (72W and $73 W$, respectively). The copper was added to the weld metal melt before the material was drawn into wire to provide a uniform copper content in the weld metal, compared to the less uniform distribution obtained with copper-coated wire. Irradiations were performed at 


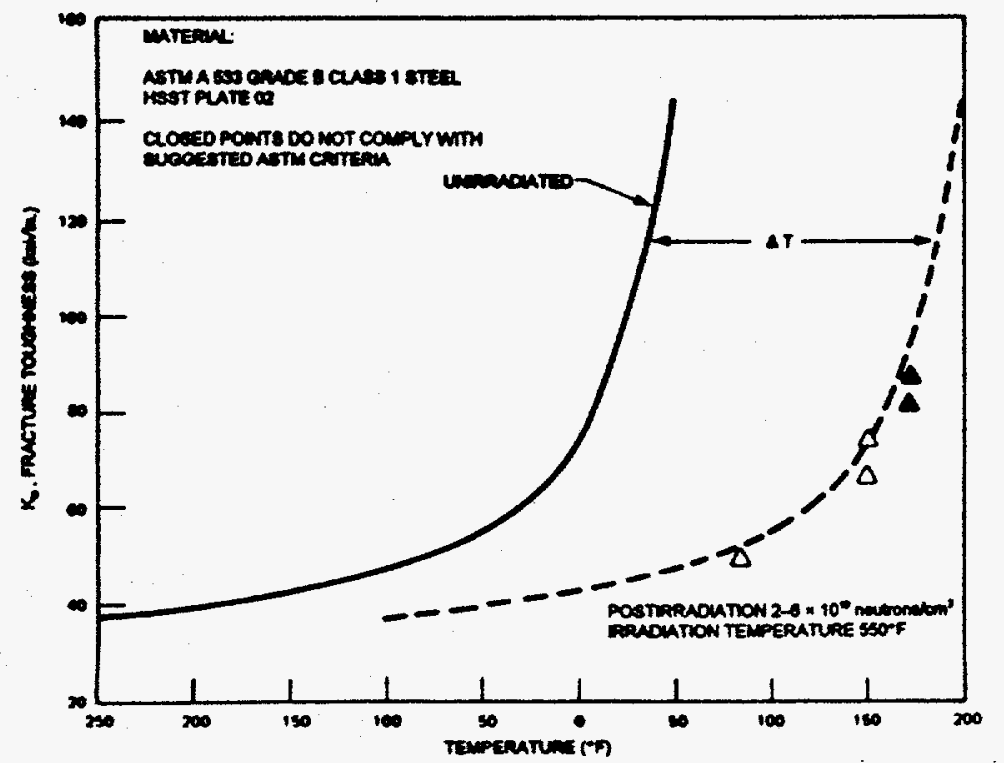

Fig. 1. Pre- and postirradiation temperature dependence of the fracture toughness $K_{k}$ of A 533 grade B class 1 steel (HSST Plate 02). Source: T. R. Mager, 1970, Post-Irradiation Testing of 2T Compact Tension Specimens, Heavy Section Steel Technology Program Technical Report No. 9, Westinghouse Nuclear Energy Systems, Pittsburgh.

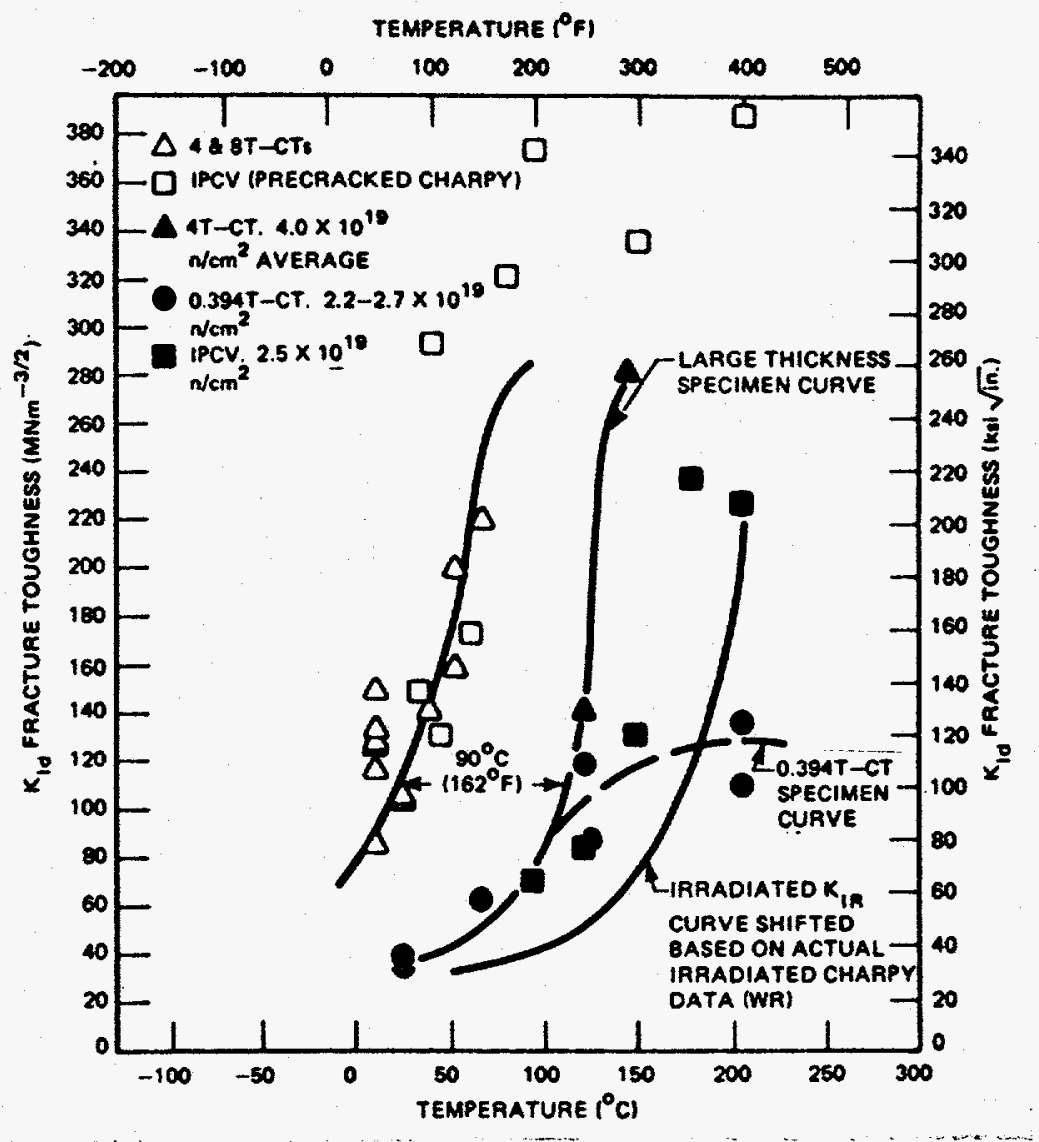

Fig. 2. Dynamic irradiated and unirradiated fracture-toughness, $K_{k d}$ (calculated using equivalent energy method), results for A 533 grade $B$ class 1 (HSST Plate 02). The 4TC(T) data lie well above the shifted $\mathrm{K}_{\mathbb{R}}$ curve and attained relatively high values of fracture toughness. Source: J. A. Davidson et al., 1976, The Irradiated Dynamic Fracture Toughness of ASTM A533, Grade B, Class 1 Sleel Plate and Submerged Arc Weldment, Heavy Section Steel Technology Program Technical Report No. 41, Westinghouse Nuclear Energy Systems, Pittsburgh. 


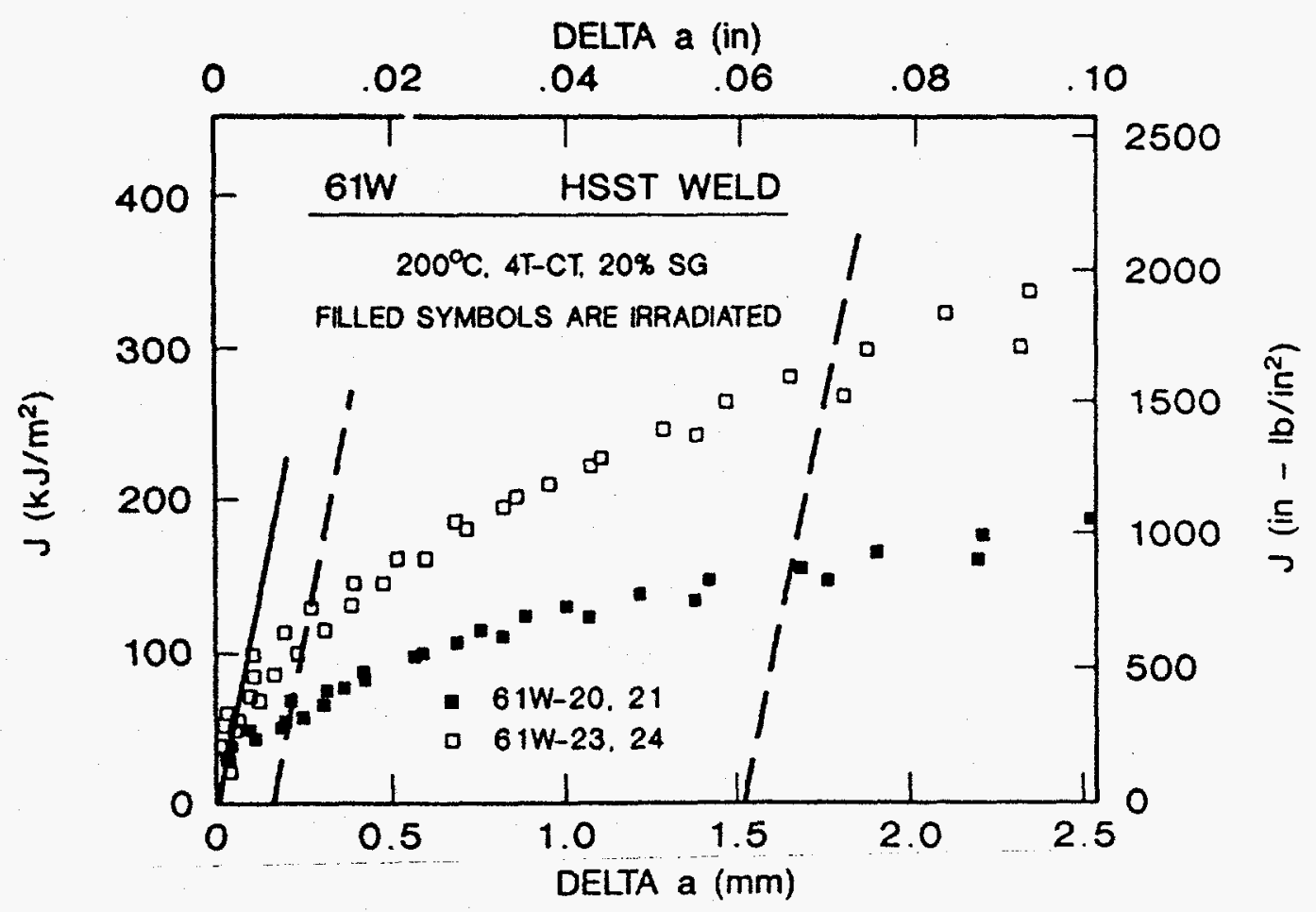

Fig. 3. J-integral vs crack extension for $4 \mathrm{TC}(\mathrm{T})$ specimens of $\mathrm{HSST}$ weld $61 \mathrm{~W}$ tested at $200^{\circ} \mathrm{C}$, unirradiated and irradiated. The ductile tearing resistance of this low upper-shelf weld has been substantially reduced by irradiation at $\sim 288^{\circ} \mathrm{C}$ to a fluence of $\sim 1.2 \times 10^{19} \mathrm{neutrons} / \mathrm{cm}^{2}(>1 \mathrm{MeV})$. Source: Hiser, A. L., et al., 1984, Materials Engineering Associates, Inc., Lanham, Md., J-R Curve Characterization of Irradiated Low Upper-Shelf Welds, USNRC Report NUREG/CR-3506 (MEA-2028).

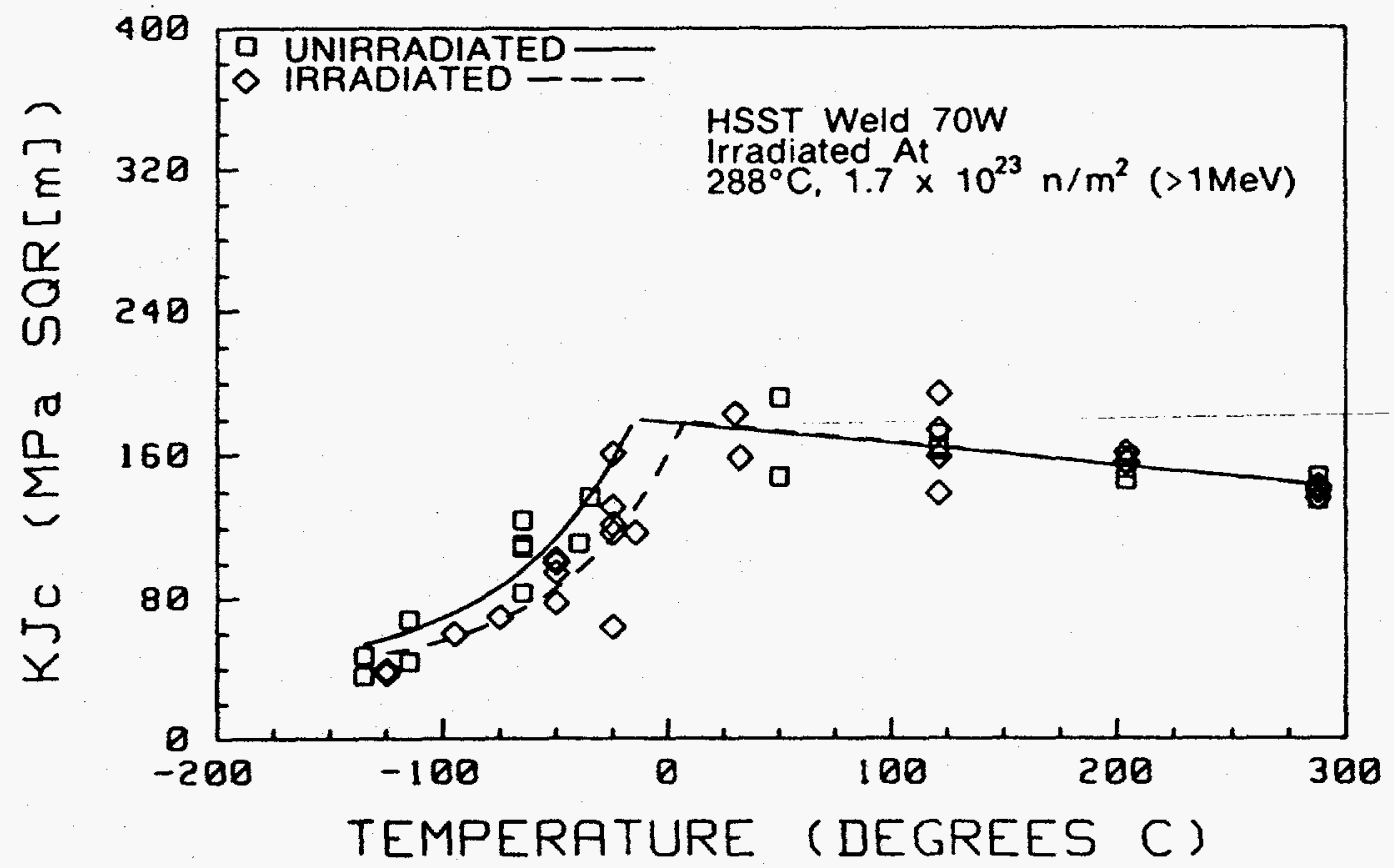

Fig. 4. Fracture toughness, $\mathrm{K}_{\mathrm{b}}$ vs test temperature for weld $70 \mathrm{~W}$ before and after irradiation at $\approx 288^{\circ} \mathrm{C}\left(550^{\circ} \mathrm{F}\right)$ to an average fluence $(>1 \mathrm{MeV})$ of $2 \times 10^{19}$ neutrons $/ \mathrm{cm}^{2}$. The effects of irradiation on this low-copper, typical-nickel weld are relatively small. 
$288^{\circ} \mathrm{C}\left(550^{\circ} \mathrm{F}\right)$ to fluences of about 1.5 and $1.8 \times 10^{19}$ neutrons $/ \mathrm{cm}^{2}$ $(-1 \mathrm{MeV})$ for the $\mathrm{K}_{\mathrm{k}}$ and $\mathrm{K}_{\mathrm{t}}$ specimens, respectively. Tests included tensile, CVN impact, drop-weight (DWT), fracture toughness, and crack-arrest toughness. Compact specimens up to 203 and $101 \mathrm{~mm}$ thick (8 and 4 in.) were tested, in the unirradiated and irradiated conditions, respectively, for the Fifth Series. Compact crack-arrest specimens up to 51 and 33 mm thick ( 2 and 1.3 in.) were tested in the unirradiated and irradiated conditions, respectively, for the Sixth Series.

The detailed results from the Fifth Series have been presented previously (Nanstad et al., 1990), (Nanstad et al., 1992a), (Nanstad et al., 1992b). For the CVN results, the 41-J (30-ft-lb) transition temperature shifts were 72 and $82^{\circ} \mathrm{C}\left(130\right.$ and $\left.148^{\circ} \mathrm{F}\right)$, while the 68-J (50-ft-lb) shifts were 82 and $105^{\circ} \mathrm{C}\left(148\right.$ and $\left.189^{\circ} \mathrm{F}\right)$ for welds $72 \mathrm{~W}$ and $73 \mathrm{~W}$, respectively. Linearized two and threeparameter nonlinear regression analyses similar in form to the $K_{k}$ curve in Sect. XI of the ASME Code gave fracture toughness temperature shifts, measured at the $100-\mathrm{MPa} \sqrt{\mathrm{m}}(91-\mathrm{ksi} \sqrt{\mathrm{in}}$.) level, of about 83 and $99^{\circ} \mathrm{C}$ (150 and $178^{\circ} \mathrm{F}$ ) for $72 \mathrm{~W}$ and $73 \mathrm{~W}$, respectively. The analyses show some decreases in slopes for the irradiated data for both welds. These decreases, however, are only about 4.1 and $6.9 \%$ for $72 \mathrm{~W}$ and $73 \mathrm{~W}$, respectively, with large enough standard errors to imply a low statistical significance of the slope changes. Figure 5 shows the fracture toughness results for weld $73 \mathrm{~W}$. When all of the irradiated fracture toughness data for $72 \mathrm{~W}$ and $73 \mathrm{~W}$ are plotted versus temperature nomalized to the $\mathrm{RT}_{\mathrm{NDT}}$, a total of eight data points fall below the ASME $K_{k}$ curve. To bound all data, the $K_{k}$ curve must be shifted upward in temperature $18^{\circ} \mathrm{C}\left(32^{\circ} \mathrm{F}\right)$.

Observations from the HSSI Fifth Irradiation Series included that the irradiation-induced temperature shift, statistical analyses and curve fitting showed that the temperature shifts at a fracture toughness of $100 \mathrm{MPa} / \mathrm{m}(91 \mathrm{ksi} / \mathrm{in}$.) were greater than those at a Charpy energy of $41 \mathrm{~J}(30 \mathrm{ft}-\mathrm{lb})$, but are in good agreement with the Charpy 68-J $(50-\mathrm{ft}-\mathrm{lb})$ transition shifts. That the 68-J $(50-\mathrm{ft}-\mathrm{lb})$ temperature shifts are greater than the $41-\mathrm{J}(30-\mathrm{t}-\mathrm{lb})$ shifts reflects the change in the slope of the CVN curves following irradiation. The results from this study and others have led to a current effort to develop alternate fracture-toughness-based methods for accounting for the temperature shift. Results from the HSSI Sixth Irradiation Series on crack-arrest toughness indicate no irradiation-induced curve shape changes in the $K_{1}$ curve (Iskander et al., 1990), (Iskander et al., 1992), (Iskander et al., 1994). Similar shifts were measured at the $41-\mathrm{J}$ (30-ft-lb) level

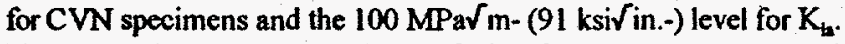
Figure 6 shows a comparison of the fracture toughness and crack-arrest toughness for the combined irradiated data for $72 \mathrm{~W}$ and $73 \mathrm{~W}$ normalized to the $\mathrm{RT}_{\mathrm{NTT}}$. The mean irradiated $\mathrm{K}_{\mathrm{k}}$ curve has been shifted much closer to the irradiated $K_{q}$ curve than is the case for the unirradiated conditions. The fact that the average separation in initiation and arrest toughness at any given temperature is reduced in the irradiated condition may help explain the enhanced propensity for pop-in events during the initiation fracture toughness tests that was observed following irradiation.

\section{Series 7 - Reactor Vessel Stainless Steel Cladding}

The objective of Series 7 is to evaluate the postirradiation properties, including fracture toughness, of the stainless steel cladding applied to the inside surfaces of LWR vessels. Cladding is applied to reactor vessels primarily to protect the coolant from contamination by corrosion products. Analyses of certain thermal shock scenarios have been inhibited by a lack of information regarding the fracture resistance of the cladding. Series 7 investigated irradiation effects on stainless steel claddings representative of those used in early pressurized water reactors (PWRs). The series was conducted in two phases with the phases being distinguished primarily by the cladding fabrication method.

The materials were austenitic stainless steel claddings deposited on A 533 grade B class 1 steel plate using two weld cladding procedures. The fabrication techniques and postweld heat treatments duplicate commercial procedures as closely as possible. However, to permit fabrication of mechanical test specimens of the cladding, multilayer depositions were utilized to provide a cladding thickness of $\approx 15 \mathrm{~mm}$ ( $0.6 \mathrm{in}$.). The two weld cladding procedures chosen for Series 7 are the single-wire oscillating submerged-arc procedure (Phase 1) and the three-wire series-arc procedure (Phase 2).

In Phase 1, the first layer of cladding was deposited using type 309 weld wire and subsequent layers using type 308 . Very high heat input during application of the first layer resulted in substantial base metal dilution (up to $50 \%$ ), and the effects on properties were significant. $\mathrm{CVN}$ and tensile specimens were irradiated at a nominal temperature of $288^{\circ} \mathrm{C}\left(550^{\circ} \mathrm{F}\right)$ to a fluence of about $2 \times 10^{19}$ neutrons $/ \mathrm{cm}^{2}$ ( $>\mathrm{I} \mathrm{MeV}$ ). CVN and tensile tests showed that the highly diluted cladding layer (adjacent to the base metal) experienced substantial radiation damage, while the cladding layers not diluted with base metal showed almost no effects of irradiation (Corwin et al., 1984). The ductile-brittle transition behavior exhibited by the stainless steel cladding was caused by failure of the delta-ferrite phase at lower temperatures (Corwin et al., 1985).

In Phase 2, a three-wire series-arc procedure was used. Irradiations were conducted at a nominal temperature of $288^{\circ} \mathrm{C}\left(550^{\circ} \mathrm{F}\right)$ to fluences of about 2 and $5 \times 10^{19}$ neutrons $/ \mathrm{cm}^{2} . \mathrm{CVN}$, tensile, and $0.5 \mathrm{~T}$ compact specimens were machined from the three-wire cladding. The CVN energy of the three-wire cladding exhibited transition temperature shifts of 13 and $28^{\circ} \mathrm{C}\left(23\right.$ and $\left.50^{\circ} \mathrm{F}\right)$ at 2 and $5 \times 10^{19}$, respectively. The CVN upper-shelf energy decreased by 15 and $22 \%$ at the low and high fluences, respectively. The $0.5 \mathrm{~T}$ compact specimens showed consistent irradiation-induced decreases in both the $\mathrm{J}_{\mathrm{k}}$ and the tearing modulus (Haggag et al., 1990). Figure 7 shows the effect of irradiation on the CVN impact lateral expansion of the three-wire cladding. Because thermal aging at relatively low temperatures (e.g., $343^{\circ} \mathrm{C}$ ) has been shown to significantly degrade the Charpy impact toughness of type 308 stainless steel welds (Alexander et al., 1990), the effects of thermal aging at reactor operating temperatures on the stainless steel cladding are being investigated. Thermal aging at $288^{\circ} \mathrm{C}$ for $1605 \mathrm{~h}$ [equal to the irradiation time in the test reactor for $5 \times 10^{19}$ neutrons $\left./ \mathrm{cm}^{2}(>1 \mathrm{MeV})\right]$ resulted in appreciable decrease $(16 \%)$ in the CVN upper-shelf energy, but the effect on the transition temperature shift was negligible (Haggag and Nanstad, 1992). The same cladding has also been aged for $20,000 \mathrm{~h}$ but the results are not yet available. Furthermore, the material is undergoing further aging to $50,000 \mathrm{~h}$.

The results of Series 7 can be summarized as follows: (1) yield strength of both single-wire and three-wire series-arc stainless claddings were increased by irradiation at prototypic LWR conditions; (2) the CVN toughness of good quality stainless steel claddings is somewhat degraded by irradiation while highly diluted cladding exhibits very poor toughness and is significantly degraded by irradiation; (3) thermal aging at the same temperature and time of irradiation indicated a significant effect on upper-shelf toughness and 


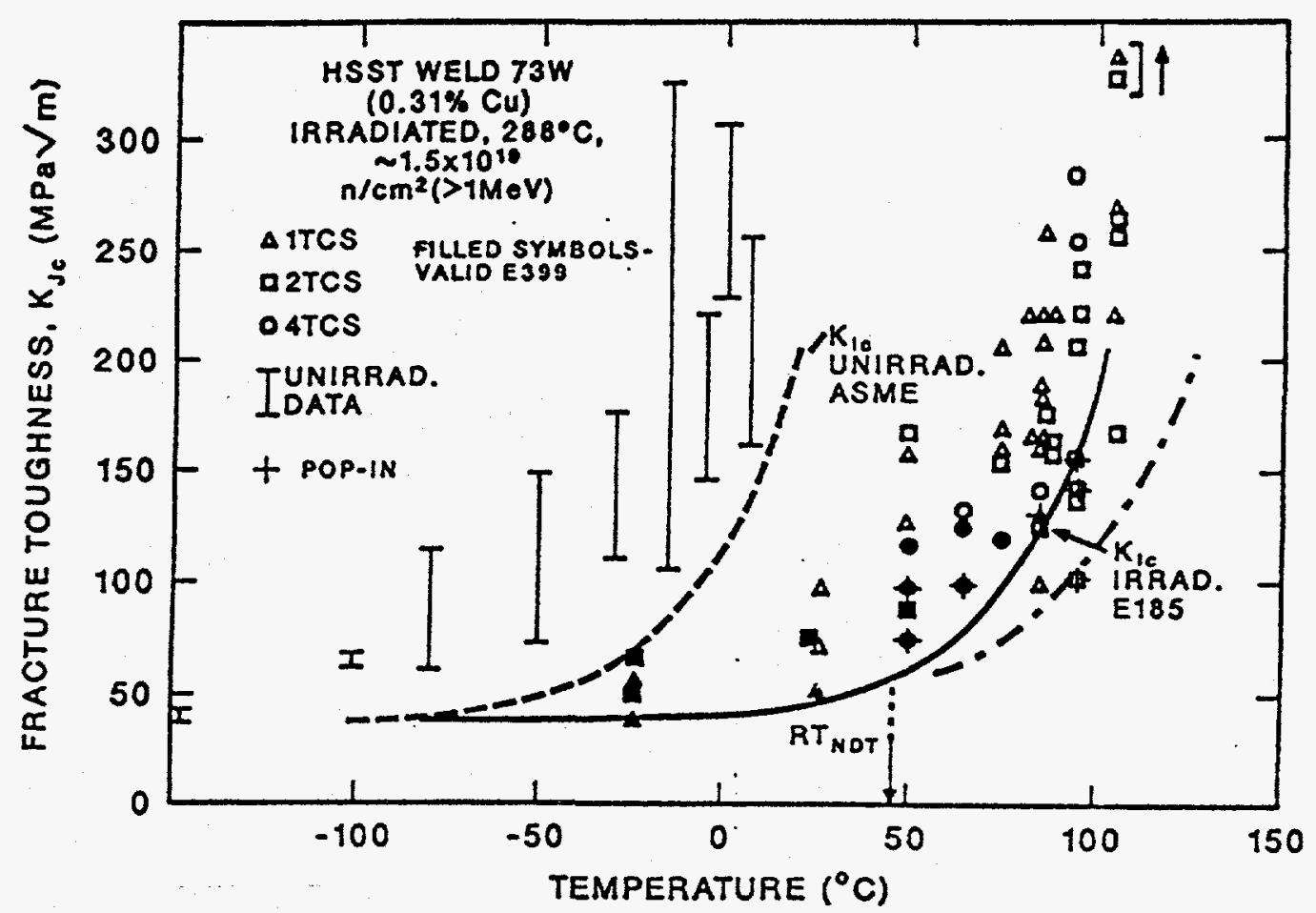

Fig. 5. Fracture toughness, $\mathrm{K}_{\mathrm{jc}}$, vs test temperature for HSSI weld $73 \mathrm{~W}$ irradiated at $288^{\circ} \mathrm{C}$ to an average fluence of $1.5 \times 10^{19} \mathrm{neutrons} / \mathrm{cm}^{2}$ $(>1 \mathrm{MeV})$. The ASME $\mathrm{K}_{\mathrm{ic}}$ Curve was shifted equal to the Charpy $41-\mathrm{J}$ shift as required by ASTM E 185 . Two cleavage fracture and four cleavage pop-in values fall below the shifted curve.
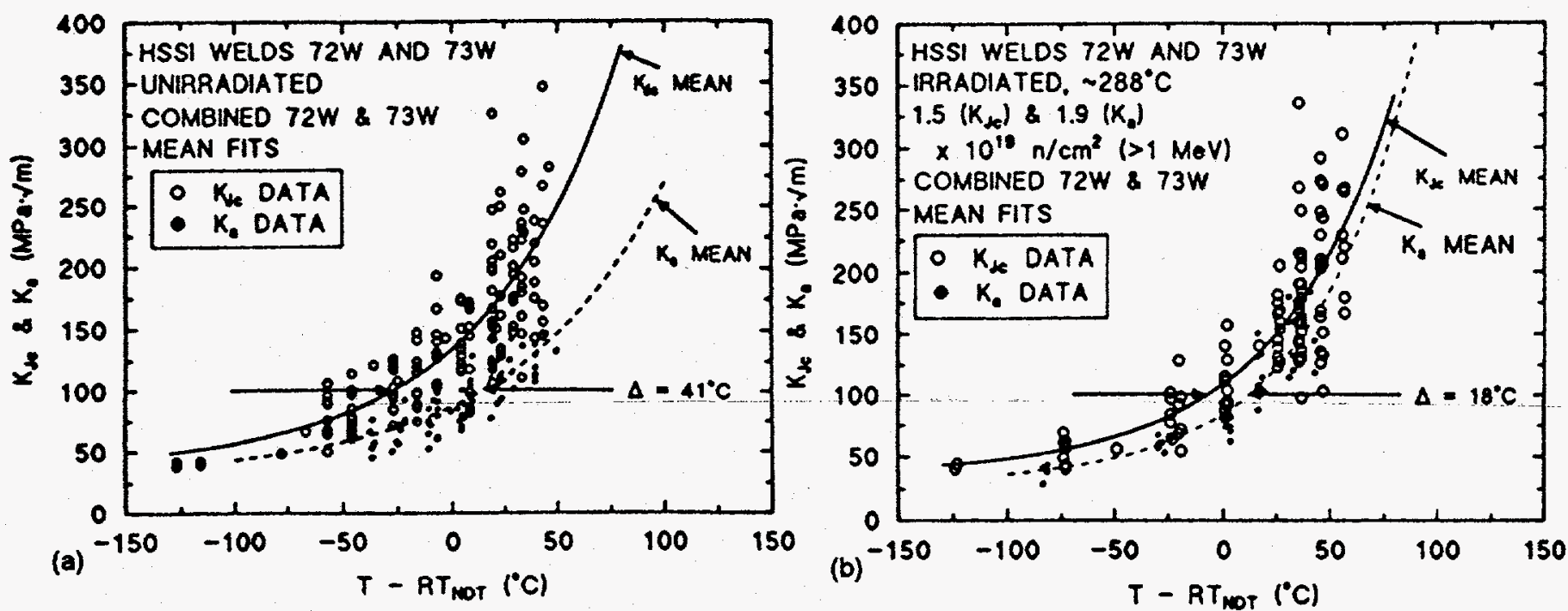

Fig. 6. Comparison of mean fracture toughness and crack-arrest toughness vs normalized temperature for welds 72 and $72 \mathrm{~W}$ in (a) unirradiated and (b) irradiated conditions. 
no effect on transition temperature, and (4) irradiation exposure reduced both the $J_{k}$ and the tearing modulus of both single-wire and threc-wire cladding.

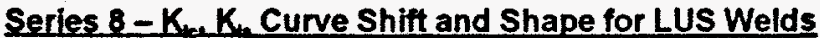

The primary objective of Series $\mathbf{8}$ is to validate the postirradiation temperature shift and shape of the ASME Code Section XI $K_{k}$ and $K_{k}$ curves for LUS high-copper welds. This series is closely related to Series 5 and 6 in its objectives except for the specific material of interest. The existing data base for $\mathbf{K}_{k}$ and $K_{\mathbf{t}}$ data of LUS welds is sparse and inadequate for determining the postirradiation temperature shift and shape of the fracture toughness and crack-arrest toughness curves. The high concentration of inclusions which promote void formation and coalescence leading to low energy tearing on the ductile shelf may likely result in different behavior in the ductile-brittle transition region as well. It is the effect of irradiation on the transition region fracture behavior of these materials which is of concern in Series 8, and direct comparisons will be made with the results of Series 5 and 6.

Series 8 is currently in the planning stage. Materials are being developed and it is anticipated that one or more weldments with copper content in the range 0.20 to $0.40 \mathrm{wt} \%$ will be utilized. The irradiation conditions for this series will be similar to those of Series 5 and 6: an irradiation temperature of $288^{\circ} \mathrm{C}\left(550^{\circ} \mathrm{F}\right)$ and a target fluence of 1.5 to $2.0 \times 10^{19}$ neutrons $/ \mathrm{cm}^{2}(>1 \mathrm{MeV})$.

\section{Series 9 - Annealing Effects in LUS Welds}

The primary objective of Series 9 is to validate the effectiveness of thermal annealing in mitigating irradiation-induced degradation of thick-section reactor vessel steels to include reirradiation response. It has been well established that postirradiation thermal annealing at temperatures in excess of the irradiation temperature can result in significant recovery of mechanical properties. Thermal annealing is being examined in specific cases as a means to restore reactor vessel safety margins and, in fact, $10 \mathrm{CFR} 50$ requires that PWRs predicted to reach the pressurized-thermal-shock (PTS) screening criteria before design end-of-life be designed for incorporation of a thermal annealing procedure. Furthermore, annealing is one potential factor in plant life extension considerations. Annealing studies reported to date have used small specimens, e.g., CVN, 0.5T-, and 1TC(T). There is little information available regarding the relationship between $\mathrm{CVN}$ and fracture toughness recovery and less about their relative relationship during reirradiation. There are also concerns that the rates of reembrittlement of fracture toughness may be rapid enough to make annealing unattractive economically. Series 9 will examine these concerns. The relationship between fracture toughness and $\mathrm{CVN}$ results in the transition temperature and ductile-shelf regions will be investigated after annealing and during reirradiation.

Series 9 is a relatively new activity. The materials being investigated include a number of materials examined in earlier series $(2,3,5$, and 6 , in particular) for which untested, irradiated specimens remain, as well as the LUS weld from the Midland reactor. If the concerns described above warrant additional examination following the testing and evaluation of these existing program materials, then a more extensive irradiation, annealing, and reirradiation will be conducted on the same LUS material being developed for Series 8 . Figure 8 shows a recent result of annealing weld $73 \mathrm{~W}$, the same weld used in the Fifth and Sixth Series.
The detailed specimen complement has not been fully planned for this series but will, of course, include CVN, tensile, and fracture toughness specimens. The initial irradiation conditions for Series 9 will probably be the same as for Series 5,6 , and 8, with an irradiation temperature of $288^{\circ} \mathrm{C}\left(550^{\circ} \mathrm{F}\right)$ and a target fluence from 1.5 to $2.0 \times 10^{19}$ neutrons $/ \mathrm{cm}^{2}(>1 \mathrm{MeV})$. The thermal annealing temperature will be concentrated at $454^{\circ} \mathrm{C}\left(850^{\circ} \mathrm{F}\right)$ with some additional work at lower temperatures. Reirradiation would be performed at $288^{\circ} \mathrm{C}\left(550^{\circ} \mathrm{F}\right)$ with the target fluence dependent on annealing results.

\section{Series 10 - Low Upper-Shelf Weld From Midland Reactor Vessel}

The principal current activity within the HSSI Program to examine LUS welds is the Tenth Irradiation Series, in which the effects of irradiation on the fracture toughness of commercially fabricated LUS submerged-arc welds from the reactor pressure vessel of the canceled Midland Unit I nuclear plant are being investigated. The welds from the Midland plant carry the Babcock and Wilcox Co. designation WF-70, a specific combination of weld wire and welding flux that exists in several commercial pressurized water reactors. The initial part of this study involved the determination of variations in chemical composition, $\mathrm{RT}_{\mathrm{NDT}}$, tensile properties, and fracture toughness throughout the welds (Nanstad et al., 1992c). Four 1.17-m-long sections of beltine weld and two similar sections of nozzle course weld have been examined. Nil-ductility transition temperatures ranged from -40 to $-60^{\circ} \mathrm{C}\left(-40\right.$ to $\left.-76^{\circ} \mathrm{F}\right)$. Because the Charpy impact energy did not achieve $68 \mathrm{~J}(50 \mathrm{ft}-\mathrm{lb})$ at NDT $+33^{\circ} \mathrm{C}\left(60^{\circ} \mathrm{F}\right)$, the $\mathrm{RT}_{\mathrm{NDT}} \mathrm{s}$ are all controlled by the Charpy behavior. The $\mathrm{RT}_{\mathrm{NDT}} \mathrm{S}$ vary from -20 to $37^{\circ} \mathrm{C}\left(-4\right.$ to $\left.99^{\circ} \mathrm{F}\right)$ with position in the vessel while the upper-shelf energies varied from 77 to $108 \mathrm{~J}(57$ to $80 \mathrm{ft}-\mathrm{lb})$. Analysis of the combined data revealed a mean $41-\mathrm{J}(30-\mathrm{ft}-1 \mathrm{~b})$ temperature of $-8^{\circ} \mathrm{C}$ $\left(18^{\circ} \mathrm{F}\right)$ with a mean upper-shelf energy of $88 \mathrm{~J}(65 \mathrm{ft}-\mathrm{lb})$. Even though both welds carry the WF-70 designation, their bulk copper contents range widely, from 0.21 to 0.34 and 0.37 to $0.46 \mathrm{wt} \%$ in the beltline and nozzle course welds, respectively.

Tensile and fracture toughness properties were determined on nozjle and beltine weld metals at six temperatures ranging from -100 to $288^{\circ} \mathrm{C}\left(-148\right.$ to $\left.550^{\circ} \mathrm{F}\right)$. The yield strength of the nozzle weld metal was significantly higher than that of the beltline weld, on the order of $100 \mathrm{MPa}(14 \mathrm{ksi})$. All the fracture toughness tests to characterize the unirradiated material, using compact specimens ranging up to $101 \mathrm{~mm}$ ( 4 in.) in thickness, have been completed. Data to characterize the fracture toughness ductile-to-brittle transition behavior were evaluated using a test standard currently urider development by the ASTM. This involves the determination of the position of a median fracture toughness transition curve (master curve), using only the data from six $0.5 \mathrm{TC}(\mathrm{T})$ specimens, all tested at the same temperature, to compare with data from large specimens. The "reference temperature" for the master curve was found to be $-60^{\circ} \mathrm{C}\left(-76^{\circ} \mathrm{F}\right)$ for the beltine weld and $-33^{\circ} \mathrm{C}\left(-27^{\circ} \mathrm{F}\right)$ for the nozzle weld. This appears to agree well with the fact that the mean fracture toughness vs temperature behavior for the beltline weld is higher than for the nozzle weld (McCabe et al., 1994).

The irradiation of the Midland weld is in progress. The exposure of two of the four small and the two large irradiation capsules, containing tensile, $\mathrm{CVN}$, and fracture toughness specimens, to the target fluences of 0.5 and $1.0 \times 10^{19}$ neutrons $/ \mathrm{cm}^{2}(>1 \mathrm{MeV})$ has been completed. 


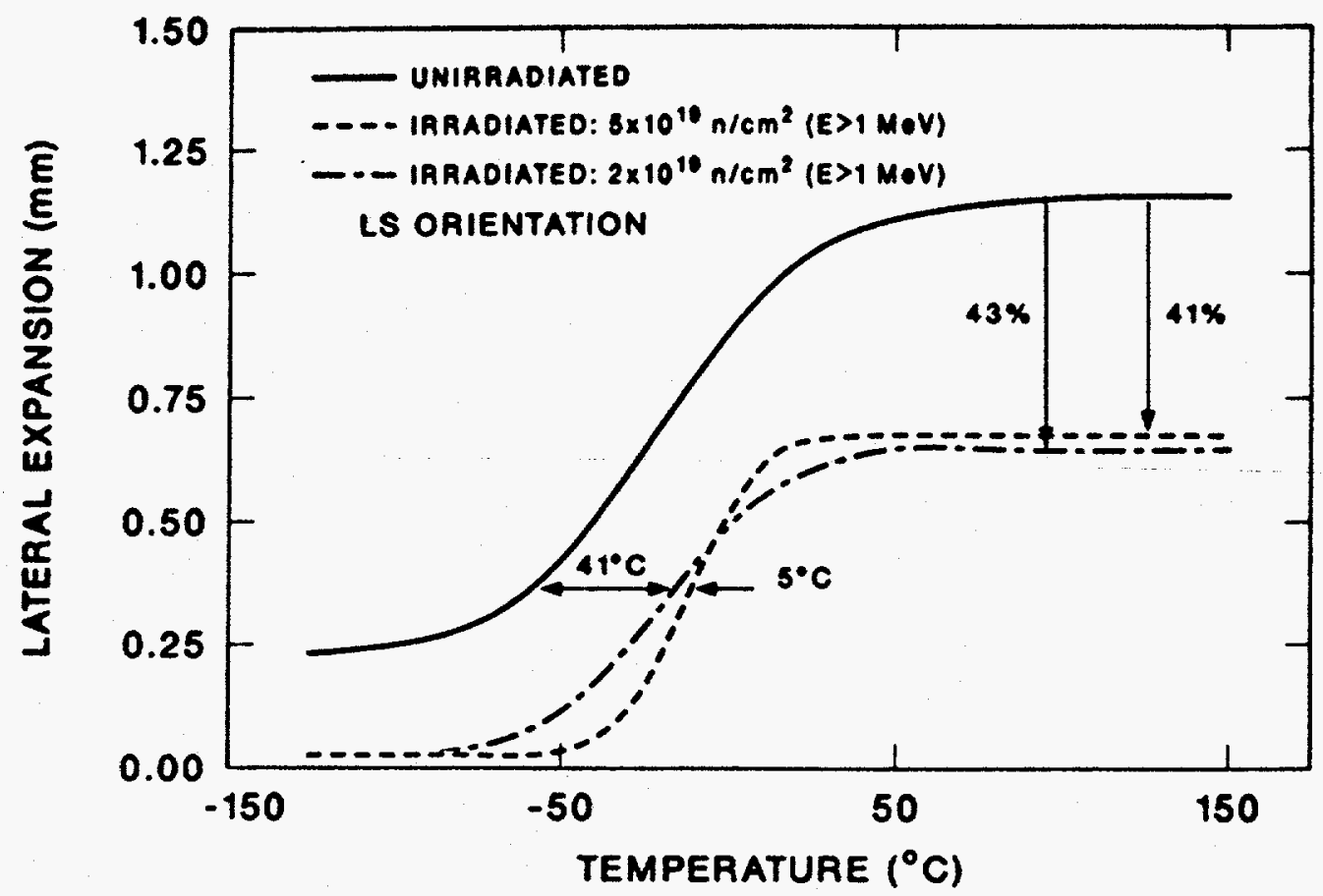

Fig. 7. Charpy impact lateral expansion vs test temperature for three-wire series-arc stainless steel weld overlay cladding, unirradiated and irradiated at $\sim 288^{\circ} \mathrm{C}$ to average fluences of $\sim 2$ and $5 \times 10^{19} \mathrm{ncutrons} / \mathrm{cm}^{2}(>1 \mathrm{MeV})$.

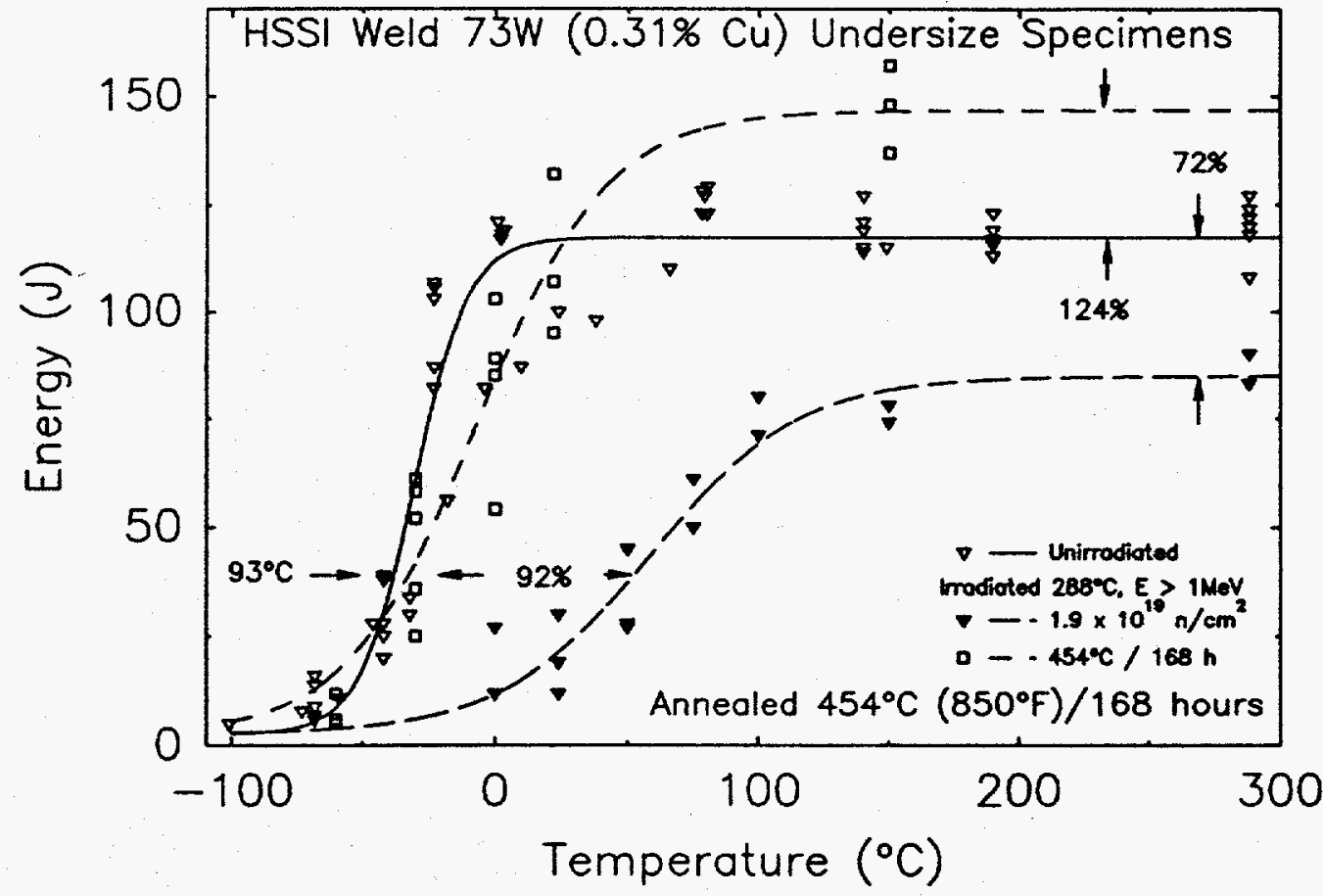

Fig. 8. Effect of thermal annealing at $454^{\circ} \mathrm{C}$ for $168 \mathrm{~h}$ on the Charpy impact energy vs test temperature for $\mathrm{HSSI}$ weld $73 \mathrm{~W}$ irradiated at $\sim 288^{\circ} \mathrm{C}$ to $-1.9 \times 10^{19}$ neutrons $/ \mathrm{cm}^{2}(>1 \mathrm{MeV})$. The annealing treatment resulted in essentially full recovery of the transition temperature and over-recovery of the upper-shelf energy relative to the unirradiated condition. 
Two additional small capsules are planned with a target fluence of $5.0 \times 10^{19}$ neutrons $/ \mathrm{cm}^{2}(>1 \mathrm{MeV})$.

\section{Series 11-Irradiation Effects on Weld HAZ and Plate Materlals}

This series shall examine the effects of neutron irradiation on the fracture toughness (ductile and brittle) of the HAZ of welds and of typical plate materials used in fabricating RPVs. The concerns to be resolved relate to the potential for early practice A 302 grade B plate and its HAZs to degrade excessively compared to existing guidance in Regulatory Guide 1.99, as well as the relative extent of fracture toughness degradation. Data will be produced to characterize the irradiated fracture toughness of this class of RPV beltine materials in both the transition and upper-shelf regimes.

Series 11 is currently in the planning stage. Materials are being identified and it is anticipated that one or more plates will be utilized for testing and for the production of HAZ materials. The irradiation conditions for this series are anticipated to utilize an irradiation temperature of $288^{\circ} \mathrm{C}\left(550^{\circ} \mathrm{F}\right)$ and a target fluence of $2.0 \times 10^{19}$ neutrons $/ \mathrm{cm}^{2}(>1 \mathrm{MeV})$.

\section{Microstructural Analysis And Modeling}

The purpose of the microstructural analysis and modeling task is to address the fundamental mechanisms which cause irradiation-induced embrittlement in RPV steels and, based upon that understanding, develop physically based models that can predict the behavior of the steels, particularly for combinations of material and exposure conditions for which direct experimental evidence is lacking. Since this activity was introduced into the irradiation effects studies, efforts have focused on the development of a model that takes into account the basic sources of embrittlement.

The embrittlement of irradiated RPV steels is believed to arise primarily from the hardening of the material due to the formation of extended defects that act to impede dislocation motion. Radiation-induced point defect clusters (PDC) and radiation-enhanced, copper-rich precipitates (CRP) provide two plausible sources for this matrix hardening. These PDC can be of either interstitial or vacancy type and could exist in either two- or three-dimensional morphologies, e.g., small loops, voids, or stacking fault tetrahedra. The formation and evolution of PDC are primarily determined by the displacement damage rate and irradiation temperature. There is experimental evidence that the size distributions of these clusters are also influenced by impurities such as copper.

The theoretical model that has been developed, based on the kinetic rate theory, investigates the relative importance of PDC and CRP in RPV embrittlement (Stoller, 1992), (Stoller, 1993), (Stoller, 1994). The model includes a detailed description of the interstitial cluster population; vacancy clustering and copper precipitation are treated in a more approximate fashion. Guidance in the choice of clustering parameters was provided by current work investigating cascade evolution in iron using molecular dynamics (MD) simulation.

The results of the calculations support the belief that PDC could provide a major source of matrix hardening, particularly at low irradiation temperatures, high displacement rates, and low doses. CRP appear to be more important at high temperatures, low displacement rates, and high doses. Because these two classes of defects exhibit such different dependencies on these major variables, any extrapolation of data that involves a significant variation in one of these variables should be carried out with caution. Although the model parameters were not adjusted to fit the data, reasonable agreement was obtained between the model's predictions and yield strength and Chappy transition temperature shift data over a range of temperatures and displacement rates. The absolute magnitude of the model's predictions are sensitive to a number of uncertain parameters; however, the predicted trends in the dose, displacement rate, and temperature dependence of hardening should be valid. With further development, the model should ultimately be useful to help guide data extrapolation and to interpret the results of LWR surveillance programs.

The dependence of the model on the CRP sink strength and the dislocation density is significant. A CRP density high enough to give rise to the observed hardening could significantly limit CRP growth by suppressing radiation-enhanced diffusion. The simple estimate of the effect of the CRP sink strength can also be used to infer that the impact of other radiation-induced and radiation-enhanced phases could be significant. This observation, along with the effect of dislocation density predicted by the model, highlights the need for more detailed microstructural characterization of RPV steels.

The magnitude of the predicted changes in yield strength due to the formation of PDC is sufficiently large to warrant more investigation of their influence. Their behavior could be particularly important in understanding and predicting the behavior of RPV steels under annealing and under subsequent reirradiation. The relative contribution of PDC and radiation-induced precipitates, and their thermal stability, needs to be determined for all the radiation/annealing conditions of interest to LWR pressure vessels.

Experimental confirmation of the presence of PDC in the numbers and sizes predicted by the current model does not presently exist. Experiments are currently under way to address this need. These same experiments are intended to investigate the uncertainty in determining the dislocation obstacle strength for small PDC in iron-based alloys and hardening superposition laws in multicomponent microstructures. More high-resolution transmission electron microscopy and atom probe field ion microscopy work is needed to better quantify the precipitate sink structure in both irradiated and unirradiated materials because of the sensitivity of the calculations to these sink strengths. This microstructural information could be used to refine the model and the values of the parameters used. Further MD studies are planned to help refine the primary damage parameters and point defect binding energies used in the model.

The model has been used to examine a broad range of irradiation and material parameters. The results indicate that there are temperature and displacement rate regimes wherein either CRP or PDC can dominate the material's response to irradiation. Both interstitial and vacancy-type defects contribute to the PDC component, with their relative importance determined by the specific irradiation conditions. The varying dependencies of the CRP and PDC on temperature and displacement rate indicate that simple data extrapolations could lead to poor predictions of RPV embrittlement.

\section{Small Specimen Techniques and Applications}

The irradiation of large fracture mechanics specimens represents a major factor in the HSSI irradiation series. As stated earlier in this paper, specimens up to $4 \mathrm{TC}(\mathrm{T})$ have been irradiated and tested in this program. From a fracture mechanics perspective, much has been learned regarding specimen size effects, within the linear-elastic regime of course, but also within the elastic-plastic regime. The use of elastic-plastic fracture mechanics and understanding of specimen size 
limitations on measuring capacity has enabled the pursuit of relatively small test specimens for the investigation of radiation effects on RPV steels. Within the current HSSI Program, these specimens include Charpy, subsize Charpy impact, precracked cylindrical tensile, and miniature disk compact specimens. Other techniques, such as automated ball indentation and microhardness, are also being pursued. The interest in small specimen technology is driven by a number of factors, e.g., vastly decreased volume of material needed for irradiation experiments, enhanced statistical analyses, and potential for fabrication of test specimens from previously tested power reactor surveillance specimens. For example, in the space taken by one 4TC(T) specimen, one can fit $641 \mathrm{~T}$ specimens or $5120.5 \mathrm{~T}$ specimens. These studies are relatively recent within the HSSI Program, but have gained visibility quite rapidly and are expected to be major aspects of research as the program continues.

\section{Thermal Embrittlement of RPV Steels}

A recent activity within the HSSI Program involved a preliminary review of thermal embrittlement of RPV steels (Nanstad et al., 1995). There are observations of thermal embrittlement, but most of the data from the literature suggest no substantial embrittlement for typical RPV steels in the temperature range of interest for up to $100,000 \mathrm{~h}$. Although there are uncertainties associated with some of those observations, the potential for thermal embrittlement for times up to 30 to 40 years cannot be dismissed based on the data available. Furthermore, the known synergistic effects of copper and nickel, as well as nickel and phosphorus, do not allow us to assume that the observations from the literature are necessarily directly indicative of the entire range of materials of interest in U.S. RPVs. The review of potential mechanisms of thermal embrittlement concluded that such aging effects are possible under the conditions evaluated but may be rare and dependent on many factors. It is felt that independent aging effects should not be simply added to irradiation-induced embrittlement. Additional studies are required to resolve these issues.

\section{SUMMARY}

The HSST and HSSI irradiation effects studies now span more than two decades of investigations which have sought to validate irradiated reactor vessel behavior. All of the investigations have contributed results having significance to the integrity analyses of reactor vessels. The observations are summarized as follows:

1. Crack initiation fracture toughness can attain high values even after irradiation.

2. Fracture toughness vs. temperature curves are shifted to higher temperatures by irradiation; the amount of shift is a function of chemical composition (e.g., $\mathrm{Cu}, \mathrm{Ni}, \mathrm{P}$ ).

3. Irradiation can markedly reduce resistance to ductile tearing, even for unirradiated welds with low tearing resistance.

4. Irradiation-induced decreases in ductile toughness and tearing resistance are roughly related to those observed for Charpy impact toughness.

5. The use of current welding practices and materials with low copper and nickel contents significantly reduces the irradiated fracture toughness degradation.

6. Some stainless steel weld overlay cladding procedures can result in cladding that is significantly embrittled by irradiation.
7. Based on irradiation of two different claddings, type 308 weld overlay cladding fabricated with low base metal dilution exhibits relatively high resistance to irradiation.

8. The shift of the $K_{k}$ curve can be greater than the CVN 41-J (30-ft-1b) shift and the curve can change shape, whereas the shift of the $K_{h}$ curve is roughly the same as that of the CVN 41 J (30 $\left.\mathrm{ft}-1 \mathrm{~b}\right)$ with no change in the shape of the curve.

9. Wide variations in the copper content and the unirradiated CVN, DWT, and fracture toughness properties have been shown to exist in commercial RPV fabrication weldments.

10. Irradiation series are either under way or planned to validate the shift and shape of the $K_{t}$ and $K_{t}$ curves for low upper-shelf welds, the response of pressure vessel materials to thermal annealing and reirradiation, the fracture behavior of an actual weld removed from an unoperated commercial PWR, and the response of older plate and HAZ materials.

11. Microstructural examinations and modeling of the mechanisms that cause embrittlement are being developed to provide a means of correlating irradiation damage produced under different conditions and an improved method for the prediction of irradiation effects.

12. Although most of the data from the literature suggest no substantial thermal embrittlement for typical RPV steels in the temperature range of interest for up to $100,000 \mathrm{~h}$, the potential for thermal embrittlement for times up to 30 to 40 years cannot be dismissed based on the data available and mechanistic considerations.

Iradiation effects is a central issue in the safe operation of existing nuclear reactor vessels, for effective design of future vessels, and for potential extension of design lifetimes. Continued research to further understanding of irradiation effects and the underlying mechanisms of radiation damage is essential.

\section{ACKNOWLEDGMENTS}

This research is sponsored by the Office of Nuclear Regulatory Research, Division of Engineering, U.S. Nuclear Regulatory Commission, under Interagency Agreement DOE 1886-8109-8L with the U.S. Department of Energy under Contract DE-AC05-84IOR21400 with Martin Marietta Energy Systems, Inc.

\section{REFERENCES}

Alexander, D. J., et al., 1990, "The Effect of Aging at $343^{\circ} \mathrm{C}$ on Type 308 Stainless Steel Weldments," Fatigue, Degradation, and Fracture, PVP-Vol. 195, W. H. Bamford, C. Becht IV, S. B. Framatome, F. D. Gilman, L. A. James, and M. Prager, Eds., American Society of Mechanical Engineers, New York, pp. 187-92.

Berggren, R G., et al., 1985, “Analysis of Charpy V-Notch Impact Toughness of Irradiated A533-B Class 1 Plate and Four SubmergedArc Welds," Effects of Radiation on Materials: Twelfh Intemational Symposium, ASTM STP 870, F. A. Garner and J. S. Perrin, Eds., American Saciety for Testing and Materials, Philadelphia, pp. 1094-1110.

Corwin, W. R., et al., 1984, Martin Marietta Energy Systems, Inc., Oak Ridge Natl. Lab., Oak Ridge, Tenn., Charpy Toughness and Tensile Properties of a Neutron-Irradiated Stainless Steel Submerged Arc Weld Cladding Overlay, USNRC Report NUREG/CR-3927 (ORNLTM-9309). 
Corwin, W. R., et al., 1985, "Fracture Behavior of a NeutronIrradiated Stainless Steel Submerged Arc Welding Cladding Overiay," Nucl. Eng. Des. 89, pp. 199- 221.

Davidson, J. A., et al., 1976, The Irradialed Dymamic Fracture Toughness of ASTM AS33, Grade B, Class 1 Steel Plate and Submerged Arc Weldment, WCAP-8775, Westinghouse Electric Corp., Pittsburgh.

Haggag, F. M., et al., 1990, Martin Marietta Energy Systems, Inc., Oak Ridge Natt. Lab., Oak Ridge, Tenn., Irradiations Effects on Strength and Toughness of a Three-Wire Series-Arc Stainless Steel Weld Overlay Cladding, USNRC Report NUREG/CR-5511 (ORNL/TM-11439).

Haggag, F. M., and Nanstad, R. K., 1992, "Effects of Thermal Aging and Neutron Irradiation on the Mechanical Properties of Stainless Steel Weld Overlay Cladding," Proceedings of the Fifth International Symposium on Environmental Degradation of Materials In Nuclear Power Systems-Water Reactors, American Nuclear Society, Inc., La Grange Park, Ml., pp. 327-332.

Hiser, A. L., et al., 1984, Materials Engineering Associates, Inc., Lanham, Md., J-R Cune Characterization of Irradiated Low UpperShelf Welds, USNRC Report NUREG/CR-3506 (MEA-2028).

Hiser, A. L., et al., 1985, "Fracture Toughness Characterization of Irradiated Low Upper-Shelf Welds," Effects of Radiation on Materials: Twelfth International Symposium, ASTM STP 870, F. A. Garner and J. S. Perrin, Eds., American Society for Testing and Materials, Philadelphia, pp. 1131-1149.

Iskander, S. K., et al., 1990, Martin Marietta Energy Systems, Inc., Oak Ridge Natl. Lab., Oak Ridge, Tenn., Results of Crack-Arrest Tests on Two Irradiated High-Copper Welds, USNRC Report NUREG/CR-5584 (ORNL/TM-11575).

Iskander, S. K. et al., 1992, "Effects of Irradiation on Crack-Arrest Toughness of Two High-Copper Welds," Effects of Radiation on Materials: 15th International Symposium, ASTM STP 1125, R. E. Stoller, A. S. Kumar, and D. S. Gelles, Eds., American Society for Testing and Materials, Philadelphia, pp. 251-269.

Iskander, S. K., et al., 1994, Martin Marietta Energy Systems, Inc., Oak Ridge Natl. Lab., Oak Ridge, Tenn., Results of Crack-Arrest Tests on Two Irradiated High-Copper Welds Phase II: Results of Duplex-Type Experiments, USNRC Report NUREG/CR-6139, (ORNL/TM-12513).

Mager, T. R., 1970, Post-Irradiation Testing of 2 T Compact Tension Specimens, Heavy-Section Steel Technology Program Technical Report No. 9, Westinghouse Nuclear Energy Systems, Pittsburgh.

MoCabe, D. E., et al. 1994, Martin Marietta Energy Systems, Inc., Oak Ridge Natl. Lab., Oak Ridge, Tenn., Unirradiated Material Properties of Midland Weld WF-70, USNRC Report NUREG/CR-6249 (ORNL/TM-12777).

McGowan, J. J., 1985, Martin Marietta Energry Systems, Inc., Oak Ridge, Natl. Lab., Oak Ridge, Tenn., Tensile Properties of Irradialed Nuclear Grade Pressure Vessel Welds for the Third HSST Irradiation Series, USNRC Report NUREG/CR-4086 (ORNL/TM-9477).

McGowan, J. J., and Nanstad, R. K., 1987, "A Statistical Analysis of Fracture Toughness of Irradiated Low-Alloy Steel Plate and Welds," Influence of Radiation on Material Properties: 13th International Symposium, (Part II), ASTM STP 956, F. A. Gamer, C. H. Henager,
Jr., and N. Igata, Eds., American Society for Testing and Materials, Philadelphis, pp. 569-589.

Nanstad, R. K., and Berggren, R. G., 1993, "Effects of Irradiation Temperature on Charpy and Tensile Properties of High-Copper, Low Upper-Shelf Submerged-Arc Welds," Effects of Radiation on Materials: 16th Intemational Symposium, ASTM STP 1175, A. S. Kumar, D. S. Gelles, R. K. Nanstad, and E. A. Little, Eds., American Society for Testing and Materials, Philadelphia, pp. 239-267.

Nanstad, R. K, ct al., 1990, "Effects of Radiation on $\mathrm{K}_{\mathrm{x}}$ Curves for High-Copper Welds," Effects of Radiation on Materials: 14th International Symposium (Volume II), ASTM STP 1046, N. H. Packan, R. E. Stoller, and A. S. Kumar, Eds., American Society for Testing and Materials, Philadelphia, pp. 214-233.

Nanstad, R. K., ot al., 1992a, Martin Marietta Energy Systems, Inc., Oak Ridge Natl. Lab., Oak Ridge, Tenn., Irradiation Effects on Fracture Toughness of Two High-Copper Submerged-Arc Welds, HSSI Series 5, USNRC Report NUREG/CR-5913, Vol. 1 (ORNL/TM- 12156/V1).

Nanstad, R. K., et al., 1992b, "Statistical Analyses of Fracture Toughness Results for Two Irradiated High-Copper Welds," Effects of Radiation on Materials: 15th International Symposium, ASTM STP 1125, R. E. Stoller, A. S. Kumar, and D. S. Gelles, Eds., American Society for Testing and Materials, Philadelphia, pp. 270-291.

Nanstad, R. K., et al., 1992c, Martin Marietta Energy Systems, Inc., Oak Ridge Natl. Lab., Oak Ridge, Tenn., Chemical Composition and $R T_{\text {NOT }}$ Determinations for Midland Weld WF-70, USNRC Report NUREG/CR-5914 (ORNL-6740).

Nanstad, R K., et al., 1995, Martin Marietta Energy Systems, Inc., Oak Ridge Natl. Lab., Oak Ridge, Tenn., Preliminary Review of Data Regarding Chemical Composition and Thermal Embrittlement of Reactor Vessel Steels, USNRC Report ORNL/NRC/LTR-95/1.

Potapovs, U., and Hawthome, J. R., 1968, The Effects of Residual Elements on $550^{\circ}$ F Iradiation Response of Selected Pressure Vessel Steels and Weldmenu, NRL Report 6803, Naval Research Laboratory, Washington, D.C.

Potapovs, U., and Hawthorne, J. R., 1969, "The Effects of Residual Elements on $550^{\circ} \mathrm{F}$ Iradiation Response of Selected Pressure Vessel Steels and Weldments," Nuclear Applications, Vol. 6, No. 1, pp. $27-46$

Stoller, R. E., 1992, Martin Marietta Energy Systems, Inc., Oak Ridge Natl. Lab., Oak Ridge, Tenn., Modeling the Influence of Irradiation Temperature and Displacement Rate on Radiation-Induced Hardening in Ferritic Steels, USNRC Report NUREG/CR-5859 (ORNL/TM-12073).

Stoller, R. E., 1993, "Modeling the Influence of Irradiation Temperature and Displacement Rate on Radiation-Induced Hardening in Ferritic Steels," Effects of Radiation on Materials: 16th International Symposium, ASTM STP 1175, A. S. Kumar, D. S. Gelles, R. K. Nanstad, and E. A. Little, Eds., American Society for Testing and Materials, Philadelphia, pp. 394-423.

Stoller, R. E., 1994, Martin Marietta Energy Systems, Inc., Oak Ridge Natl. Lab., Oak Ridge, Tenn., A Comparison of the Relative Importance of Copper Precipitates and Point Defect Clusters in Reactor Pressure Vessel Embrittlement, USNRC Report NUREG/CR-6231 (ORNL-6811).

"Title 10," Code of Federal Regulations, Parts 0 to 199, January 1987, U.S. Government Printing Office, Washington, D.C. 
Whitman, G. D., 1986, Martin Marietta Energy Systems, Inc., Oak Ridge Natt. Lab., Oak Ridge, Tenn., Historical Summary of the Heavy-Section Sleel Technology Program and Some Related Activities in Light-Water Reactor Pressure Vessel Safety Research, USNRC Report NUREG/CR-4489 (ORNL-6259).

Williams, J. A., 1975, The Irradiated Fracture Toughness of ASTM A533, Grade B, Class 1 Steel Measured with a Four-Inch-Thick Compact Tension Specimens, HEDL-TME 75-10, Hanford Engineering Development Laboratory, Richland, Wash.

\section{DISCLAIMER}

This report was prepared as an account of work sponsored by an agency of the United States Government. Neither the United States Government nor any agency thereof, nor any of their employees, makes any warranty, express or implied, or assumes any legal liability or responsibility for the accuracy, completeness, or usefulness of any information, apparatus, product, or process disclosed, or represents that its use would not infringe privately owned rights. Reference herein to any specific commercial product, process, or service by trade name, trademark, manufacturer, or otherwise does not necessarily constitute or imply its endorsement, recommendation, or favoring by the United States Government or any agency thereof. The views and opinions of authors expressed herein do not necessarily state or reflect those of the United States Government or any agency thereof. 